\title{
НЕВЫПОЛНИМАЯ МИССИЯ СОВЕТСКОЙ ВНЕШНЕЙ ПОЛИТИКИ
}

\begin{abstract}
Аннотация. Настоящая статья посвящена одной аналитической записке, представленной на рассмотрение Генерального секретаря ЦК КПСС Ю.В. Андропова. Резкое обострение конфронтации между Советским Союзом и коалицией западных держав в конце 70-х годов поставило перед советским руководством ряд кардинальных вопросов совершенствования советской внешней политики. Наступление на позиции запада требовало громадного перенапряжения материальных и духовных ресурсов страны, превышавшего её возможности. Для обеспечения коммунистической мессианской экспансии и ведения холодной войны Советский Союз расходовал от 15 до $30 \%$ своего ВВП (США примерно 5\%). Это грозило подорвать экономические основы существования страны. Советское руководство грубо нарушало фундаментальный принцип внешней политики, сформулированный еще Клаузевицем - поставленные внешнеполитические цели должны строго соответствовать имеющимся материальным ресурсам и международным условиям. Однако вместо того, чтобы смягчать напряженность в отношениях $с$ Западом и снизить давление не только на экономику Советского Союза, но и его партнеров по Организации Варшавского Договора, Кремль пошел в коние 70-х годов на обострение этой напряженности.
\end{abstract}

Ключевые слова: международные отношения, политика, СССР, геополитика, Андропов, дипломатия, идеология, интересы, безопасность, иенности.

$\mathrm{P}$ азмещение на позициях советских ракет SS-20 в Европе и последовавшее ответное решение НАТО от 12 декабря 1979 г. об установке в Европе американских ракет «Першинг-1» и «Першинг-2», а также крылатых ракет, способных долететь до Москвы в считанные минуты, ввод советских войск в Афганистан, попытки Кремля расширить советское влияние в Третьем мире - все это привело к подрыву разрядки и резко обострило политическую и военную конфронтацию. Лишь угроза взаимного уничтожения удерживала стороны от открытого столкновения.

Критическая оценка этих неразумных шагов советского руководства, их влияния на международную ситуацию и на положение стран социалистического содружества была дана в моей аналитической записке «Некоторые соображения о внешнеполитических итогах 70-х годов». 15 января 1980 г. она была отправлена директором Института экономики мировой социалистической системы АН академиком О. Бого- моловым в ЦК КПСС. Особое внимание в ней было уделено войне в Афганистане, начатой в конце декабря 1979 г.:

«Введением войск в Афганистан наша политика, очевидно, перешла допустимые границы конфронтации с Западом в "третьем мире». Выгоды от этой акции оказались незначительными по сравнению с ущербом, который был нанесен нашим интересам:

1. В дополнение кдвум фронтам противостояния в Европе против НАТО и в Восточной Азии против Китая - для нас возник третий опасный очаг военно-политической напряженности на южном флланге СССР, в невыгодных географических и со- циально-политических условиях, где нам придется иметь дело с объединенными ресурсами США и других стран НАТО, Китая, мусульманских государств и повстанческой армии афганских феодально-клерикальных кругов, обладающих сильнейшим влиянием на афганский народ. Впервые после Второй мировой войны мы оказались перед возможной перспективой локального военного конфликта, в котором, в отличие от корейского, вьетнамского и других, нам придется воевать собственными войсками. В связи с этим возрастает угроза военной эскалации;

2. Произошло значительное расширение и консолидация антисоветского фронта государств, опоясывающего СССР с Запада до Востока;

3. Значительно пострадало влияние СССР на движение неприсоединения, особенно на мусульманский мир; тические предпосылки для ограничения гонки вооружений;

5. Резко возрос экономический и технологический нажим на Советский Союз;

6. Западная и китайская пропаганда получила сильные козыри для расширения кампании против Советского Союза в целях подрыва его престижа в общественном мнении Запада, развивающихся государств, а также сочиалистических стран;

7. Афганские события, как и кампучийские, надолго ликвидировали предпосылки для возможной нормализации советско-китайских отношений;
4. Заблокирована разрядка и ликвидированы поли- 


\section{Международные отношения International Relations}

8. Эти события послужили катализатором для преодоления кризисных отношений и примирения между Ираном и США;

9. Усилилось недоверие к советской политике и дистанцирование от нее со стороны СФРЮ, СРР и КНДР. Даже в печати ВНР и ПНР впервые открыто обнаружились признаки сдержанности в связи с акциями Советского Союза в Афрганистане. В этом, очевидно, нашли свое отражение настроения общественности и опасения руководства указанных стран быть вовлеченными в глобальные акции Советского Союза, для участия в которых наши партнеры не обладают достаточными ресурсами;

10. Усилилась дифреренцированная политика западных держав, перешедших к новой тактике активного вторжения в среру отношений между Советским Союзом и другими социалистическими странами и открытой игре на противоречиях и несовпадении интересов между ними;

11. На Советский Союз легло новое бремя экономической помощи Афганистану.

Таким образом, эскалация противоборства между СССР и западными державами, а также Китаем в «третьем мире» поставила к кониу 70-х годов под угрозу важнейшие завоевания политики разрядки. На дальнейшее наращивание нашего военно-политического наступления в "третьем мире» Запад будет отвечать все большим сползанием назад в «холодную» или "полугорячую» войну и резким усилением давления на Советский Союз по всем линиям - политической, экономической, военно-стратегической и пропагандистско-психологической. Постепенному возвращению к политике разрядки могло бы способствовать свертывание нашей военной активности в "третьем мире», если, конечно, кризисные ситуации не перекинутся на другие регионы, особенно в Восточную Европу. Принятие подобного курса предполагает значительное расширение экономических, научно-технических и культурных отношений с развивающимися странами, т. е. перенос центра тяжести на использование мирных средств повышения влияния социализма в "третьем мире» и поддержки молодых развивающихся государств.

В создавшейся ситуации дальнейшее развитие процессов разрядки представляется маловероятным без решения афганского кризиса на компромиссной основе. Можно предполагать, что Вашингтон, продолжая показную пропагандистскую кампанию против "советской интервенции», вместе с тем постарается максимально использовать присутствие советских войск в Афганистане для подрыва международных позиций СССР. В таком случае США рассчитывают получить редкостную возможность навязать Советскому Союзу затяжную изнурительную войну с афганскими повстанцами в исключительно неблагоприятных для него условиях, оставаясь сами в положении "третьего радующегося». В этом, однако, позиции Вашингтона расходятся с мнением правительств Франции, ФРГ и других западноевропейских государств, считающих, что подобный курс в корне подорвет разрядку и что поэтому надо искать взаимоприемлемое урегулирование афганского вопроса, пока для этого имеются еще предпосылки, создав для Советского Союза условия для вывода войск без потери престижа. В случае неуступчивости в этом вопросе с нашей стороны Соединенным Штатам удастся навязать Западной Европе свой курс.

Сейчас особое значение приобретает фактор времени. До весенней распутицы в Афганистане мы еще располагаем свободой политического маневра. С началом лета и активных действий арганских повстанцев, если наши войска будут втянуты в серьезные бои, такая возможность исчезнет».

Вскоре мне стало известно, что и наш Генеральный штаб придерживался примерно такой же позиции и возражал против ввода советских войск в Афганистан. Больше того, оказалось, что советскому вторжению в эту страну во многом содействовала политика США. Советник американского правительства Збигнев Бжезинский разработал весьма коварный провокационный план. По секретным каналам до сведенья советского руководства была доведена ложная информация о якобы планирующейся высадке войск США в Афганистан. Это послужило поводом для Политбюро ЦК КПСС принять решение об упреждении американской высадки. Для США война Советского Союза в Афганистане принесла серьезный выигрыш в геополитическом, экономическом и пропагандистско-психологическом отношении.

Очень скоро это стало очевидным и для советского руководства. Вероятно, именно поэтому в начале 1982 г. мне поручили подготовить для Ю.В. Андропова аналитическую записку об основных вопросах отношений Советского Союза со странами социалистического лагеря, Запада и Третьего мира. К тому времени я хорошо освоился с этой проблематикой и составил представление о том, насколько неадекватным и ущербным для национальных интересов Советского Союза был тогдашний внешнеполитический курс нашей страны. Мне уже в течение десяти лет довелось руководить отделом международных отношений в Институте экономики мировой социалистической системы АН и наблюдать, что и как готовилось на нашей «государственной внешнеполитической кухне».

ИЭМСС безуспешно пытался с помощью многочисленных аналитических записок внушить Брежневу, 


\section{История международных отношений / History of international relations}

Громыко и другим руководящим лицам, что внешнеполитический курс, выработанный еще во времена Сталина, не отвечает современным реалиям. Подготовка этих материалов была своеобразным «искусством возможного» для советников руководства на всех уровнях политического планирования. Лишь немногие храбрецы могли решиться перейти «грань дозволенного» и открыто, без обиняков высказать руководству свое мнение. Для некоторых это оканчивалось изгнанием из руководящих органов, как это было, например, с руководителем группы консультантов при отделе социалистических стран ЦК КПСС Александром Бовиным.

Мне было известно, что Андропов несравненно более терпимо, чем Брежнев, относился к новым, непривычным идеям, и даже поощрял их постановку. Это побудило меня высказать в записке все, что я думал тогда о советской внешней политике. Это было не легкой задачей. Но ее необходимо было выполнить, учитывая тот внешнеполитический и экономический тупик, в котором Советский Союз оказался на рубеже 1970-х и 1980-х гг. Серьезность положения побуждала откровенно написать об устаревших, ошибочных концепциях советской внешней политики.

10 января 1983 г. записка была отправлена в секретариат Андропова. На основе исторического опыта XX в. в ней была сформулирована универсальная закономерность возникновения и развития глобальной конфронтации - «обратная отрицательная связь», или «защитная реакция», которая срабатывает всякий раз, когда какая-либо великая держава пытается навязать свои ценности и свой порядок другим государствам и установить свое господство. Эта закономерность сохранила свое значение и поныне.

В центре записки стояли проблемы вывода Coветского Союза из состояния ненужной и опасной конфронтации с Западом, которая поглощала лучшие силы нашей страны и делала невозможным решение более важных задач внутреннего развития. Собственно, речь шла о путях прекращения «холодной войны». Подобная историческая задача могла быть решена только радикальным пересмотром идеологических принципов тогдашней политики, прежде всего, путем отказа от «классовой борьбы» на международной арене и от мессианской роли Советского Союза как «движущей силы» "коммунистического и национально-освободительного движения», что служило основанием для советской экспансии и вмешательства во внутренние дела государств. Это должно было привести к значительным переменам - к отказу от брежневской доктрины «ограниченного суверенитета» и от концепции «стратегического паритета» с Западом, к установлению равноправных партнерских отношений с социалисти- ческими странами Восточной Европы и других регионов. Только так можно было ослабить интенсивность «обратной отрицательной связи» западных держав в противодействии советской экспансии и создать условия для сбалансирования политических интересов с Западом, для реального процесса разоружения, устранения угрозы ядерной войны и преодоления «холодной войны».

Аналитическая записка носила на первый взгляд сугубо абстрактное название: «Методологические аспекты определения степени угрозы возникновения войны». В действительности же, за этим названием скрывалось рассмотрение острейших вопросов тогдашней советской политики и выдвижение целого ряда предложений по её кардинальному изменению. В принципе для того времени это выглядело довольно вызывающим фрондерством, облеченным в теоретическую форму.

При Брежневе, который крайне болезненно реагировал на все новаторские идеи и старался не отходить от сталинских внешнеполитических концепций, невозможно было и подумать о представлении на его рассмотрение подобных идей. Но после того как Генеральным Секретарем ЦК КПСС в ноябре 1982 г. был избран Андропов, многое пришло в движение. Будучи много лет председателем КГБ (1967-1982 гг.), он лучше других знал, что за брежневским фасадом кажущейся стабильности развивались процессы, которые могли иметь разрушительные последствия для тогдашнего советского общества. Для него было ясно, что экономическая и социальная эффективность существовавшей в Советском Союзе системы никак не отвечала тогдашним стандартам общественного развития и грозила обернуться политической угрозой для советской власти. По многим критериям Советский Союз был не в состоянии состязаться с Западом.

Было очевидно, что сверх централизованное планирование и всесильный бюрократический аппарат тормозили здоровое развитие общества. В эпоху Брежнева к этому добавились зачатки разложения морали, этики, дисциплины и ответственности, широкое распространение цинизма, халатности и отступление от социалистических ценностей. Исчезал былой коммунистический пуританизм.

Будучи убежденным коммунистом и творческим человеком, Ю.В. Андропов был настроен устранить недостатки, которые накопились в советском обществе и в политике. Эксперименты Андропова по децентрализации планирования и управления экономикой, по расширению самостоятельности и простора для деятельности предприятий и коллективов, по усилению нравственности наталкивались на сопротивление консервативных, догматически настроенных престарелых 


\section{Международные отношения International Relations}

деятелей в Политбюро, в ЦК и в правительстве. Но всё же за короткий срок пребывания на посту Генерального Секретаря он пробудил в обществе ожидания и надежды на реформы закостенелой советской системы. Мне казалось, что и во внешней политике могут наступить положительные перемены. В надежде на это и была написана аналитическая записка. Ниже следует её текст.

«В 80-е годы резко возросла угроза новой мировой войны. Является ли эта угроза подобной другим, имевшим место ранее и не приведшим к войне? Пли сейчас опасность третьей мировой войны значительно более реальна? Чтобы ответить на этот вопрос, необходимо определить причины и механизм возникновения мировой войны. Если они имеют общий характер, можно надеяться выработать методологию подхода к таким вопросам, как возникновение войны и возможные меры ее предотвращения. Это поможет установить и современный уровень военной опасности, нависшей над человечеством.

Но перед тем, как перейти к решению этой задачи, мы должны сформулировать основные качественные особенности мировых войн. Они сводятся к следуюшему:

1. Появление мировых войн как международного явления связано с образованием иелостной системы международных отношений, которая вовлекала в свою орбиту все новые и новые государства-участницы мирового сообщества и чем дальше, тем больше - усиливала степень их взаимозависимости, сложного взаимодействия их национально-государственных интересов и переплетения их взаимной безопасности. "Люди, - говорил В.И. Ленин, - живут в государстве, а каждое государство живет в системе государств. Которые относительно друг друга находятся в системе известного политического равновесия» (m.42, с. 59). Нарушение этого равновесия порождало международные кризисы, перераставшие в мировые войны, в которые как по цепной реакции втягивались крупные державы и следовавшие в их фарватере страны. Поэтому саморасширяемость является одной из наиболее характерных черт мировых войн.

2. Самые значительные успехи агрессора (нападающей стороны) в начале войны не имели решающего значения и, в конце концов, война заканчивалась его поражением. Объяснение этому надо искать в том, что правящая верхушка великой державы, развязавшей мировую войну во имя распространения своей гегемониальной власти, всякий раз грубо нарушала главный принцип и первейшее правило внешней политики: ставить перед собой задачи и цели, строго соответствующие внутренним и международным возможностям их реализации. Наблюдался парадоксальный факт - этот принцип, приобретший аксиоматическое значение, все признавали на словах, но полностью игнорировали на деле, что вело к тягчайшим поражениям.

3. От войны к войне росли ее масштабы, разрушительность средств ее ведения и число ее жертв. Последние достижения человеческого гения в области ядерной, ракетной, электронной, лазерной и других видов техники придали, наконеи, мировой войне апокалипсический характер и поставили человеческую цивилизацию перед угрозой самоуничтожения.

4. Причинами мировых войн выступают особые, не разрешимые обычными политическими методами противоречия. Обе последние мировые войны были следствием развития противоречий внутри капиталистической системы. После 1945 г. водораздел противоречий пролег между странами капитализма и социализма, и сейчас человечество стоит на пороге третьей мировой войны именно вследствие крайнего обострения этих противоречий на мировой арене.

5. Ни одна мировая война не была неожиданной. Ee приближение видели и понимали. Предпринимались попытки предотвратить ее. Но ни разу это не удалось сделать. Все это говорит о том, что мировые войны возникают вследствие некоего процесса, который еще не удалось до конца понять, а потому и предотвратить, приостановить. Приступим к его поиску, применяя системный подход.

Пусть некая держава стремится резко усилиться и расширить сферу своего гегемониального влияния. Каковы будут последствия этого для мирового сообщества? Слабые страны вольно или невольно будут подчиняться этой державе, ее господству. Она будет становиться еще сильнее и подчинять более сильные государства и т.д., пока мир не превратится в одно сверхгосударство или определенный политический порядок под гегемонией этой державы. Но этого до сих пор не произошло. Объясняется это тем, что в системе мирового сообщества существует обратная отрицательная связь к усилению отдельного государства (державы) и расширению сферы его господства до пределов, которые начинают угрожать интересам других государств, особенно великих держав.

Результатом действия этой отрицательной обратной связи является объединение сильных государств в «антикоалицию» против потенциально 


\section{История международных отношений / History of international relations}

или реально сильнейшего (в регионе, мире). Уровень эфрфективности обратной связи измеряется достаточностью или избыточностью, т.е. с некоторого момента усиление названной державы должно либо полностью компенсироваться, либо вследствие создания превосходящего противовеса приводить к ослаблению ее международных позиций. На практике реализуется последний вариант, причем с нарастающей мощью за счет вступления в "антикоалицию» новых государств и максимальной мобилизации их материальных, духовных и людских ресурсов.

Итак, первый блок образуется посредством насильственного или ненасильственного и даже добровольного присоединения слабых к сильному, а второй путем объединения главным образом сильных против сильнейщего. Это полностью подтверждается составом военных союзов в мировых войнах.

Можно подметить интересные особенности: во-первых, "антлкоалщия» сплочена главным образом страхом перед общим врагом, и, во-вторых, агрессор явно не может выиграть войну - любой его успех вызывает избыточное усиление "антикоалиции». Действительно, США вступили в первую и вторую мировые войны именно в момент наибольшего ослабления "антикоалиции» - в апреле 1918 г. и в декабре 1941 г. Так разрастается мировая война, и чем больше успехи агрессора, тем сильнее. "На всякой войне, - указывал В.И. Ленин, - противники, силы которых уравновешиваются, останавливаются на некоторое время, копят силы, отдыхают, переваривают пережитый опыт, готовятся и - бросаются в новый бой» (m. 13, c. 72).

Действие обратной отрицательной связи может ослабляться рядом фракторов. Например, если сила агрессора сплачивает врагов, то его слабость должна вызвать колебания в стане "антикоалиции», что подтверждается, к примеру, позицией США и Англии в конце второй мировой войны. Трудности в создании и деятельности "антикоалиции» могут возникнуть и в результате противоречий среди ее действительных или потенциальных участников. Так, острейшие противоречия между СССР и западными державами не позволили своевременно воссоздать в 1938-1939 гг. Антанту и построить систему коллективной безопасности против угрозы нацистской агрессии. Это стоило СССР, Франции и Англии больших жертв и потерь. Но рано или поздно обратная отрицательная связь должна обязательно сработать.

"Антикоалиция» со временем неизбежно настолько усиливается, что противостоящая ей держава и возглавляемый ею союз оказываются не в состоянии выдержать военное и экономическое противоборство. Следовательно, всякий экспансионизм и гегемонизм таит в себе зародыш собственной гибели. Об этом говорит опыт мировых войн.

Мы показали применимость системного подхода, по крайней мере, как поискового метода, для выявления механизма возникновения и развертывания мировой войны. Попробуем использовать его для анализа послевоенного развития событий.

По окончании мировой войны "агрессор» становится второстепенной державой. Он не опасен, "антикоалиция" добилась своего. Но среди участников самой "антикоалиции» неизбежно найдется сильнейший, который необыкновенно укрепился, обрел ореол победителя, расширил среру своего влияния и стал представлять не меньшую опасность, чем раньше "агрессор». "Антикоалиция», направленная против прежнего врага, распадается. Но взамен намечается или создается комбинация держав или новая "антикоалиция», направленная уже против бывшего союзника, если он становится на путь расширения своей гегемониальной сферы. Весь процесс повторяется при новом составе участников. Но немедленно начаться война не может, т.к. силы главных государств-победителей примерно равны. Кроме того, психологически трудно начать войну против недавнего союзника. Для этого нужна довольно длительная подготовка народа и всей страны. Необходимо также расширение и укрепление «антикоалиции» и m.d.

После первой мировой войны в Европе возникла качественно новая международная ситуация, преобразившая традиционную расстановку и соотношение сил на континенте. Это было результатом победы в России Великой Октябрьской сочиалистической револючии и образования Советского государства провозвестника нового общественного строя - антипода капитализму. С точки зрения рассмотрения предмета нашего исследования важно подчеркнуть, что это событие имело далеко идущие международные последствия, присоединив к старым межимпериалистическим противоречиям новый острейший узел противоречий между Советским государством и капиталистическими державами, в основу которых легла классово-социальные, идеологические факторы. Это оказало серьезнейшее влияние на характер действия обратной отрицательной связи и формирование европейского баланса сил.

Поражение Германии и Австро-Венгрии, револючия, Гражданская война и послевоенная разруха в России привели к тому, что господствующие позиции в европейских делах заняли Франция и Англия. Они продиктовали европейским народам несчастный Версальский мир, содержавший в себе уже с самого начала зародыш будущей мировой войны. Стремле- 


\section{Международные отношения International Relations}

ние каждой из этих держав занять гегемониальное положение в Европе было парализовано действием обратной отрицательной связи. И это произошло сравнительно легко, ибо, во-первых, их претензии взаимно уравновешивались, а, во-вторых, их силы были неадекватны той роли, на которую они притязали. Для Советского Союза Англия и Франция выступали тогда державами, от которых исходила основная опасность для социалистических завоеваний. Поэтому развитие противоречий с ними носило наиболее острый характер. Эти противоречия переоценивались даже тогда, когда глазная угроза завоеваниям социализма стала исходить от германского фашизма. Играя на расколе между государствами бывшей "аятикоалиции», Германия смогла восстановить свою военную мощь, выступить с еще более широкомаситабными планами экспансии, чем во времена Кайзера. Но тем самым она неизбежно воссоздала против себя "антикоалицию" на еще более широкой, глобальной основе, что привело к сокрушительному разгрому фашистской Германии.

После второй мировой войны действие обратной отрицательной связи приобрело намного более сложный и интенсивный характер. В основу ее формирования легло противоборство между силами капитализма и социализма в качественно изменившихся условиях ядерной эпохи и научно-технической революции. На это наслаивалось влияние таких факторов глобального значения, как выход социализма за рамки одной страны и возникновение ряда социалистических стран в Восточной Европе, на Дальнем Востоке, в Юго-Восточной Азии и других регионах, крах колониальной империи Запада, небывалый размах движений за национальное и социальное освобождение.

Непосредственным результатом второй мировой войны явилось резкое ослабление главных капиталистических держав, кроме США, нажившихся и укрепившихся в ходе войны. Германия и Япония были разгромлены и выбыли из числа великих держав. Англия и Франция превратились во второразрядные державы. Остальные государства Западной и Восточной Европы находились в шатком положении экономической разрухи и социального брожения под действием дискредитации капитализма, громадного роста антифашистских, демократических настроений. С другой стороны, позиции социалистической державы - Советского Союза необычайно упрочились. Его военная мощь и морально-политический авторитет поднялись на небывалую высоту.

В новых условиях наиболее правильным представлялось использовать неизмеримо возросшее могущество Советского Союза, особенно его военную мощь, для продвижения социализма и отвоевания позиций у капиталистического Запада. Этот путь и был избран. Исторически он был на первый взгляд понятным и оправданным. Но тем самым центр тяжести классовой борьбы был как бы смещен на межгосударственные отношения между СССР и западными державами во главе с Соединенными Штатами. Это предопределило последующее развитие главных международных процессов на мировой арене и привело к последствиям, которые в первые послевоенные годы трудно было предвидеть. Особенно это касается роста угрозы ядерной войны.

Итак, в результате беспрецедентного усиления Советского Союза, его перехода к активному наступлению на позиции мирового капитализма в действие была приведена обратная отрицательная связь, которая рано или поздно должна была сплотить против него большинство великих держав мира. Уже в конце войны появились симптомы распада "антикоалиции». Опасаясь, что вакуум силы, образовавшейся в Центральной и Восточной Европе, будет заполнен Советским Союзом, западные державы стали на путь создания новой, уже антисоветской коалиции, включившей в себя и часть побежденной Германии. Потребовалось всего 4 года, чтобы эта коалиция - НАТО - стала действительностью. На ее вооружение была взята стратегия «сдерживания», затем "отбрасывания», "ядерного устрашения», "гибкого реагирования» и пр.

В первые послевоенные годы реальность опасного объединения Запада против СССР не осознавалась или осознавалась слабо, точно так же, как накануне 1-й и 2-й мировых войн правящие круги Германии не осознавали, что своими действиями они сколачивают против себя "антикоалицию». Здесь сказывалась и переоценка межимпериалистических противоречий с нашей стороны.

Идентифицировав себя в теории и на практике с ролью руководителя, главной силы, оплота социалистического лагеря, как тогда говорили, Советский Союз взял на себя тем самым необычайно трудное экономическое и политическое бремя борьбы против главных сил империализма. Послевоенная структура международных отношений приняла на 10-15 лет биполярный характер. Стоило сделать на этом пути один шаг, как логика борьбы заставляла делать последующие, подталкивая все дальше и дальше в неизвестное. Эта логика с неумолимой силой продолжает действовать и ныне, при новом поколении людей и государственных деятелей, когда маховик противоборства за долгие годы оказался раскрученным почти до отказа, так что его необычайно трудно замедлить, а тем более остановить.

Ход событий не оправдал и расчетов на то, что все страны, консолидировавшиеся на пути социали- 


\section{История международных отношений / History of international relations}

стического развития, признают руководящую роль Советского Союза и что отношения между Советским Союзом и другими странами социализма можно будет строить на основах, как бы напоминающих внутрипартийный принцип "демократического централизма», перенесенный на международную арену. Оказалось, что в наш век гегемониальная роль - под каким бы лозунгом она ни выступала - вызывает противодействие со стороны как капиталистических, так и - не в меньшей степени - социалистических государств. Но в первые послевоенные годы трудно было поверить в то, что в оппозицию Советскому Союзу перейдет целый ряд социалистических стран. Впоследствии ими стали Югославия, Китай, Албания, в той или иной форме - КНДР, Румыния. Еще невероятнее казалась идея, что во взаимодействие с "антикоалицией» против СССР вступит социалистический Китай.

Следовательно, отрицательная обратная связь может проявлять себя независимо от социальноклассовой природы государств-субъектов международных отношений и приводить к созданию «антикоалиции» смешанного социально-политического состава. Первые симптомы этого обнаружились вскоре после победы Октябрьской сочиалистической революции в России, когда Франция, Англия и США предложили Советскому правительству свою помощь, если оно согласится продолжить войну против Германии на стороне Антанты. Во второй мировой войне возникла, хотя и с большим запозданием, «антикоалиция» стран, принадлежавших к разным социальным системам. Эта особенность обратной связи сохранилась и в послевоенный период.

Для правильной оченки характера и интенсивности действия обратной связи очень важно составить четкое представление, как противная сторона воспринимает политику СССР, его цели на международной арене. При этом, конечно, надо делать скидку на классово-ограниченный характер этих восприятий. В глазах западных политиков Советский Союз предстает как опасная держава, руководство которой последовательно и целеустремленно осуществляет, главным образом посредством военного насилия, мессианскую цель ликвидации капитализма и установления коммунистического строя советского типа во всем мире, постоянно наращивая свою «экспансию» и расширяя сферу своего господства. В доказательство этого на Западе приводятся следующие доводы:

1. В 1939-1940 г2. Советский Союз присоединил Латвию, Литву л Эстонию, Западную Украину и Западную Белоруссию, Бессарабию, часть территории Финляндия;
2. В период 1945-1950 гг. он установил свое господство над странами Восточной и частично Центральной Европы, присоединил Закарпатскую Украину, часть японских островов;

3. В 60-х годах он предпринял первые попытки продвинуть свое влияние на Ближний Восток, в ЮгоВосточную Азию и другие регионы (Египет, Индонезия и др.);

4. Во второй половине 70-х годов он „перелил через край“, вышел за пределы уже созданных срер влияния, начав "активное вторжение» на Ближний Восток, в Африку, в Юго-Восточную и Юго-Западную Азию, в Центральную Америку (Ангола, Эфиопия, Йемен, Мозамбик, Афганистан и др.);

5. Расширение сореры советского влияния сопровождалось все усиливающимся ростом военной мощи Советского Союза. В результате он оказался в состоянии на рубеже 80-х годов выдвинуть требование о "военно-стратегическом равновесии между силами империализма и социализма», а фактически между СССР, с одной стороны, США, Англией, Францией, ФРГ, Италией, Японией, Канадой и Китаем - с другой. Создание советским руководством такой огромной военной мощи на Западе связывается с интересами обеспечения дальнейшей «глобальной экспансии» Советского Союза.

6. Советское руководство, как указывают западные политики, не скрывает своих целей на международной арене, о чем свидетельствуют использовавшийся одно время лозунг "Мы вас закопаем», а затем постоянное подчеркивание в официальных советских заявлениях и программных документах стремления изменить соотношение сил в мире в пользу социализма (а фрактически - СССР) в ущерб капитализму (западным державам), утверждения, что такое изменение уже наступило, открытая постановка задачи об усилении влияния реального социализма /СССР/ на ход мировых событий и пр.

В соответствии с этой оценкой характера намерений и действий советского руководства Соединенные Штаты и их союзники рассматривают все события и явления международной жизни, а также прогрессивные социальные процессы во внутреннем развитии отдельных стран почти исключительно сквозь призму противоборства с Советским Союзом. Это, бесспорно, намного затрудняет деятельность прогрессивных сил, движений, партий и организаций в зоне капитализма и в развивающемся мире, обрушивая на них массированные репрессии и ненужный огонь со стороны Запада. Выходит, что объективно другой стороной тесной "завязанности» Советского Союза на антиимпериалистические движения 


\section{Международные отношения International Relations}

является сужение, ограничение возможностей развертывания процессов социального и национального освобождения, не говоря уже о том, что это опасно подрывает советский экономический потенциал. На деле от этого страдают интересы мирового социализма. Такова причудливая логика истории.

Интересно рассмотреть вопрос, как соотносятся действие обратной отрицательной связи и разрядка напряженности в отношениях СССР - США и в более широком контексте - между Востоком и Западом. Означает ли возникновение на рубеже 70-х годов феномена разрядки отрицание обратной связи как определенной закономерности международной жизни? На наш взгляд, это было бы неверным выводом.

Появление разрядки было вызвано рядом объективных причин и соображениями западных политиков о перенесении противоборства с СССР в иную плоскость. С одной стороны, главные капиталистические страны преодолели к 70-м годам послевоенные трудности, стабилизировались в экономическом и социальном отношении, возникли три мощных центра силы капитализма в лице США, Западной Европы и Японии. С другой стороны, мир сочиализма перестал быть моноцентрическим в результате раскола между Китаем и СССР, значительной дифференциации позиций социалистических стран и роста противоречий между ними. В оценках Запада в "третьем мире» Советскому Союзу не удалось в 50-х и 60-х г2. создать существенных плацдармов и опорных пунктов для расширения своего влияния.

Все эти процессы протекали на фоне если не установления ракетно-ядерного равновесия между США и СССР, то по крайней мере достижения Советским Союзом уровня достаточности ракетно-ядерных сил, который делал для США неприемлемым глобальный ядерный конфликт. В этих условиях взоры западных политиков, естественно, обратились к мирным средствам достижения антисоветских политических целей, особенно путем поощрения центробежных сил в мире социализма. В случае удачи это сулило Западу дальнейшее ослабление международных позиций СССР и сужение базы его влияния. Для проведения такой политики требовались отход от «холодной войны», устранение остроты во взаимоотношениях с ССС, развитие с ним сотрудничества, достижение компромиссных договоренностей по широкому кругу вопросов. Это соответствовало и интересам советской политики. Так, с начала 70-х годов разрядка стала набирать силу, достигнув своего апогея на общеевропейском совещании в Хельсинки, затем пошла на убыль и сменилась состоянием крайней напряженности в отношениях между СССР и Западом к началу 80-х годов.
Очевидно, для США и их союзников дальнейшее существование разрядки было бы приемлемо лишь при условии сохранения и соблюдения со стороны Советского Союза международно-политического и военно-стратегического статус-кво, как он сложился на начало 70-х годов. Но этого не случилось. В представлении Запада, советское руководство активно использовало разрядку для наращивания своих военных сил, чтобы добиться ракетно-ядерного паритета с США и вообще с противостоящими державами. Во-вторых, оно воспользовалось «внешнеполитическим параличем» США, вызванным "вьетнамским синдромом», в целях продвижения своих интересов в Африке, на Ближнем Востоке и в других регионах. Тем самым Запад пришел к выводу, что советское руководство не оставило своих планов экспансии. Это расчистило дорогу к власти самым реакционным, оголтелым кругам империализма США и других стран НАТО, круто повернувшим руль политики в сторону конфронтации.

Для Советского Союза разрядка давала редкостный шанс I) продемонстрировать свое стремление снизить противоборство с Западом до минимального уровня и тем самым предотвратить прочесс наращивания сил "антикоалиции", 2) обратить всю свою энергию и ресурсы на решение внутренних задач социально-экономического укрепления страны, перевода экономики на путь интенсивного развития, что также должно было снизить действие обратной отрицательной связи и ослабить "антикоалицию", 3) подтянуть тылы, укрепить всю систему связей и сотрудничества в рамках СЭВ и ОВД на основах социалистического партнерства, 4) найти новые пути и формы поддержки национально-освободительных движений, которые бы не наносили ущерба разрядке.

К сожалению, этот шанс был упущен, и Советский Союз оказался перед лицом нового небывалого нажима империализма. Этот поворот в политике обошелся ему (в сопоставлении только с военными расходами (ША) в 1,5 триллиона долларов, если не больше, на пятилетие 1981-1986 гг. и вызвал опасный рост военной напряженности.

Опыт истории говорит о том, что в противоборстве сторон наступает определенный переломный момент, когда дальнейшие сдвиги в соотношении политических и военно-стратегчческих сил становятся больше совершенно неприемлемы для «антикоалиции», и она переходит к решительным контрдействиям, не останавливаясь перед крайними мерами. Перед второй мировой войной такой критический момент наступил с захватом Германией Чехословакии. Стало ясно, что Гитлер намерен взломать европейский ба- 


\section{История международных отношений / History of international relations}

ланс сил и затем выступить против своих главных противников на Западе и Востоке Европы. Поэтому на его очередной шаг - нападение на Польшу западные державы ответили объявлением войны. Напал ли Гитлер в сентябре 1939 г. на Польшу, если бы заранее знал, что против него вскоре объединится весь мир? Вряд ли он рискнул бы тогда начать мировую войну. К тому же он ее формально и не начинал. Он спровоцировал ее своими действиями, которые вытекали из его общей концепции установления господства в Европе.

Итак, мы видим: критические изменения в соотношении сил могут вызвать такой высокий накал международной напряженности, что любое неосторожное действие (Сараево, Данциг) способно спровоцировать "неадекватную» реакцию и привести к войне.

В послевоенный период расширение сферы советского влияния достигло в глазах Запада критических пределов с введением советских войск в Афганистан. В былые времена это уже само по себе могло послужить для "антикоалиции» поводом для развязывания войны. Но угроза взаимного ядерного уничтожения не позволила Западу прибегнуть к лобовому военному столкновению с СССР. В условиях, когда ядерная война не может рассматриваться как рациональное средство достижения политических целей, "антикоалиция" обратилась к заменяющим ее рычагам давления. Среди них главное место заняли массированная гонка вооружений, максимальное увеличение военно-экономического пресса на экономику ССС, ставка на военно-техническое превосходство, объединение духовных и материальных ресурсов капиталистического мира против Советского Союза. Поставлена задача проведения «крестового похода» против СССР.

Нынешняя политика США и их союзников подпадает под определение «избыточной обратной связи». Это означает, что мир вступил в крайне опасную, кризисную полосу развития, которая может привести к новой мировой войне. Упование на ядерное устрашение и гарантированное ядерное уничтожение, как фактор сдерживания войны, могут оказаться роковой иллюзией.

Действие обратной связи поставило уже Советский Союз во внешнеполитическом плане в крайне тяжелое положение. Против него объединились фактически все великие державы мира, кроме разве Индии. Задачи противостояния их многократно превосходящему потенциалу опасно превосходят возможности Советского Союза.

Поиски путей ослабления "избыточного» давления "антикоалиции» на Советский Союз составляет ныне, по-видимому, одну из центральных задач со- ветской внешней политики. Совершенно очевидно, что этого можно добиться только путем постепенного самоограничения и осторожных действий Советского Союза на внешней арене.

В современных условиях Советский Союз не может быть глобальным гарантом и защитником мирового революционного и национально-освободительного движения. Это непосильная задача. К тому же в этом нет надобности. Ныне не та обстановка, что была в 1945-1950 г2. Социализм превратился в неодолимую силу, а процессы социального обновления приобрели необратимый характер. С точки зрения сохранения и укрепления мира и дальнейшего развития мирового социализма крайне необходимо, жизненно важно, чтобы центр тяжести классовой борьбы снова переместился из сферы межгосударственных отношений СССР - Запад в среру внутреннего социально-политического развития капиталистических стран и государств "третьего мира». Первый важный шаг, содействующий движению в этом направлении, был сделан в Политической декларации стран-участниц Варшавского Договора от 5 января 1983 г., где они подчеркнули свое стремление строго отделить в своей политике идеологические вопросы от проблем межгосударственных отношений. Ныне настало время - и его опасно упускать - чтобы распространить это положение и на другую критическую область отношений СССР - Запад, где угрожающе нарастают внешнеполитические противоречия и конфлликты между ними, - на среру их вовлеченности во внутренние социальные и национальные процессы, происходящие в "третьем мире», а также в развитых капиталистических странах. Этого, естественно, не легко будет добиться, учитывая, что противоборство Советского Союза с западными державами зашло слишком далеко. Тем не менее движение в этом направлении еще возможно. Для этого необходимо, чтобы наша политика убедительно продемонстрировала на практике (после солидного теоретического обоснования и разъяснения нашим друзьям за рубежом) существенный пересмотр ориентиров своей деятельности на внешней арене, в коммунистическом и национально-освободительном движениях с учетом того, что национальным отрядам этих движений надлежит в условиях ядерной опасности больще полагаться на собственные силы в строгом соответствии с особенностями социально-политической и экономической ситуации в каждой стране, чем на военную помощь СССР. Только в этом случае возникнут предпосылки для ослабления действия обратной связи в ущерб СССР и международной стабильности и для радикальной реорганизации политических отношений между Советским Союзом 


\section{Международные отношения International Relations}

и Западом. Судя по опыту прошлого, в создавшейся обстановке это представляется единственным путем, способным прервать и нейтрализовать международные процессы, которые неотвратимо ведут к ядерной войне. Другого, пожалуй, не дано.

Такой поворот в нашей политике отнюдь не предполагает какого-то «социалистического изоляционизма» в национальных рамках. Наоборот, он намного расширит почву для межнационального взаимодействия и взаимного влияния и взаимообогащения сил социализма в политической, экономической, теоретической, научной и культурной сферах. Социалистическая солидарность станет богаче, приобреmет естественный, органичный характер.

Что касается западных держав, то они неизбежно вынуждены будут постепенно перейти к свертыванию конфронтации с СССР и изменить свою политику в "третьем мире» под угрозой ее полной дискредитации (как это сейчас происходит в Ливане, в Центральной Америке и т.д.). Это откроет простор для развертывания межимпериалистических противоречий и приведет к распаду "антикоалиции», к громадному выигрышу сил социализма.

На протяжении нашего века характер и содержание классовой борьбы за социализм не оставались неизменными. Они существенно менялись в зависимости от складывавшихся условий в рамках отдельных стран и в международном маситабе, а также от индустриалъного и научно-технического прогресса человечества. До 1917 г. эта борьба велась главным образом на национальной почве. В межвоенный период ее характер в целом сохранялся, хотя Советский Союз все активнее и шире выступал как международный фактор поддержки социалистического и коммунистического движения в странах иной социальной системы (китайской революции, испанских республиканцев и т.д.). После 1945 г. эта роль Советского Союза неизмеримо возросла. В результате он оказался в положении острейшей конфронтации с главными силами мирового империализма. Смещение центра тяжести классовой борьбы на международную арену привело к тому, что определяющей в ней стала сорера военного противостояния и противоборства. Ракетно-ядерное оружие придало этому противоборству исключительно опасный, рискованный характер.

Поэтому в современной ситуации классовая борьба наполнилась для сил социализма новым смыслом и содержанием. Ее приоритетной задачей стало спасение человечества от ядерного уничтожения. Речь идет о существовании каждого из нас, наших детей и внуков, о жизни или смерти нынешнего поколения людей, о судьбе будущих поколений. Задача заключается в том, чтобы вывести классовую борьбу на международной арене из опасной среры ядерной конфронтации. Сейчас особенно злободневно звучат слова В.И. Ленина о том, что "с точки зрения основных идей марксизма, интересы общественного развития выше интересов пролетариата...» (m. 4, с. 220).

Совершенно новые задачи классовой борьбы в ядерный век требуют и радикально новых путей и методов их реализации. Преимущественно контрсиловые методы - это не решение вопроса. Они все ближе подталкивают человечество к пропасти ядерной войны. Кроме того, элементарная логика подсказывает, что размеры экономического и научно-технического потенциала Советского Союза в сопоставлении с потенциалами противостоящих держав не позволят ему выдержать напряжение борьбы на истощение.

Вполне очевидно также, что одними переговорами без коренной реорганизации политических отношений СССР - Запал невозможно решить проблему обуздания гонки вооружений и снижения опасности войны. Дело в конечном счете не в том, каким количеством и качеством оружия располагает та или иная сторона, а в том, насколько достижим политический модус вивенди между СССР и западными державами. Именно здесь, в политической сфере, лежит ключ к разгадке тайны разоружения и снижения угрозы войны. Om этой сферы будет зависеть и дальнейшее действие обратной отрицательной связи, сплоченность и сила или ослабление и внутренняя разобщенность "антикоалиции», противостоящей СССР.

Одной из важнейших мер по снижению политических противоречий СССР - Запад могло бы стать договорное признание со стороны Советского Союза, а также США и других западных стран, что социальный прогресс, выбор социально-политического строя и путей социально-экономического развития должны осуществляться исключительно на национальной почве, в рамках отдельных государств, без вмешательства извне. Правда, это положение уже нашло отражение в ряде официальных документов. Но на деле оно не соблюдается, и вопрос заключается в том, чтобы сделать его действительной нормой международного поведения, чтобы оно нашло практическую реализацию во внешней политике. Очевидно, здесь не обойтись без крупных уступок с нашей стороны, без изменений наших концептуальных внешнеполитических установок. В.И.Ленин учил, что если наступление зашло слишком далеко и создало опасную ситуацию, надо уметь и отступить. Сейчас это диктуется высшими соображениями спасения человеческой цивилизации.

Потребуется и пересмотр ряда теоретических положений, особенно под углом зрения наполнения 


\section{История международных отношений / History of international relations}

новым содержанием принципа интернационализма, выработки основ социалистического партнерства как краеугольного камня взаимоотношений между социалистическими странами в современных условиях. Не менее важна психологическая перестройка, способность освободиться от представлений о характере и задачах классовой борьбы, о требованиях единства, которые были правильны и оправданны для второй половины XIX и первой половины XX вв., но утратили значение или совершенно видоизменились по содержанию в наше время.

Если удастся сместить центр тяжести классовой борьбы снова на национальный уровень, это развяжет огромные внутренние силы социального прогресса, справиться с которыми империалистические круги Запада окажутся не в состоянии. Надо иметь в виду, что общество в самих ведущих капиталистических державах давно созрело для перехода к социализму, даже в несравненно большей степени, чем в любом из развивающихся государств. Ослабление противоборства СССР - Запад, снятие с повестки дня тезиса о "советской угрозе» может значительно ускорить движение общественных сил западных стран к социализму.

Наконеи, возвращение центра тяжести классовой борьбы на национальную почву позволило бы нам сосредоточиться на реализации основополагающей ленинской идеи о том, что свое влияние на революционное движение, на мировой социальный прогресс Советский Союз должен оказывать главным образом и в первую очередь своими хозяйственными успехами»

Главная идея записки - найти пути ликвидации холодной войны и все силы бросить на внутреннее развитие страны - не осталась без внимания Андропова. Она нашла отражение во многих его выступлениях, в которых подчеркивалось, что классовая борьба должна уступить место задаче спасения человечества от ядерного апокалипсиса.

В годы перестройки эту идею удалось воплотить в жизнь в ходе реформирования советской внешней политики и дипломатических усилий, направленных на создание качественно нового, мирного порядка в Европе и во всем мире. 21 ноября 1990 г. представители 22 государств Европы, а также Соединенных Штатов Америки и Канады подписали в Париже основополагающий международный акт, который подвел черту под холодной войной. Он вошел в историю как Парижская хартия. В ней торжественно провозглашалось: «Мы, главы государств и правительств стран-участниц Конференции по безопасности и сотрудничеству в Европе собрались в Париже во время глубоких перемен и исторических ожиданий. Эра конфронтации и раскола в Европе закончилась. Мы объявляем, что наши отношения в будущем будут основываться на уважении и сотрудничестве. Европа освобождается от прошлого. Благодаря мужеству мужчин и женщин, воли народов и силе идей Заключительного акта Хельсинки в Европе наступает новая эра демократии, мира и единства... Настало время, когда веками лелеемые надежды и ожидания наших народов становятся явью. Это непоколебимая приверженность демократии, основанной на правах и основных свободах человека, благосостояние, достигаемая посредством экономической свободы и социальной справедливости, и равная безопасность для всех наших народов». Впервые в истории был достигнут общеевропейский консенсус, отвечавший национальным интересам всех европейских народов.

Но великим идеям Парижской хартии не суждено было сбыться. Виной тому выступили два фактора. Без малого год спустя после её принятия в результате предательской деятельности Ельцина и фатальных провалов во внутренней политике Горбачева не стало Советского Союза и с таким трудом и жертвами построенной социалистической системы. Воспользовавшись этим, США перешли к активной политике глобального господства и созданию «пакс американа». Это в корне противоречило принципам Парижской хартии, и они были выброшены Соединенными Штатами за борт. От них в реальной жизни не осталось и следа. Народы были обмануты в своих «веками лелеемых надеждах и ожиданиях». 